\title{
Hygienic Food Practice among Food Workers in Jordanian Food Factories during pandemic crisis: COVID-19:comparative study
}

sharaf omar ( $\boldsymbol{\nabla}$ sharaf@bau.edu.jo)

Research article

Keywords: COVID-19, Food hygiene practice, Knowledge, Attitude, Food Handlers, Jordan

Posted Date: May 29th, 2020

DOI: https://doi.org/10.21203/rs.3.rs-29784/v1

License: (c) (i) This work is licensed under a Creative Commons Attribution 4.0 International License.

Read Full License 


\section{Abstract}

Food borne disease is transmitted easily among food handlers working in food factories. This study aimed to evaluate hygienic food practice among food handlers working in food factories in Jordan during pandemic crisis: COVID-19. A total of 500 food handlers in 25 food factories were participated in this question survey study. The knowledge of food handlers during COVID-19 pandemic was higher than their knowledge before COVID-19 pandemic with a mean percentage score of $83.4 \pm 8.3 \%, 73.3 \pm 10.8 \%$ respectively. In general, the food handlers attitude toward safe food handling during COVID-19 was higher than their attitude before COVID-19 with mean percentage score of $91.3 \% \pm 12.7$ and $88.36 \% \pm 10.7 \%$ respectively. The awareness of food handlers in Jordanian factories for COVID-19 requirements was with a mean percentage score of $70.4 \% \pm 14.9 \%$. Our study showed that fair knowledge for food handlers in food safety doesn't necessary reflect their positive attitude. The overall scores for this study were $79.13 \%$ . Enforcement the governmental regulations, increasing the number of education and training courses and encourage the positive behavior food handlers would improve the status of food hygiene during COVID-19.

\section{Introduction}

COVID-19 virus is still threatening the life of many people all over the world. World Health Organization (WHO) advice many countries to follow the physical distance between individuals to reduce disease transmission. This advice can easily applied on many businesses, schools, and institutes of education. In food industry the chance to work from home is difficult, and the workers need to work in their working places, so there is a big challenge for keeping food workers in along food chain safe and healthy during COVID-19 pandemic (Wei, W.et al. 2020).

The current evidence approved that COVID-19 virus affect the respiratory system and transmitted through coughing or sneezing, there is no evidence for transmission of COVID-19 virus by food as well as the virus cant multiply in food and need human or animals to multiply in it. Infection can be occurred if someone touched any contaminated surfaces, objects such as door knobs, faucets and hands then touching his eyes or nose (Tong,Z. et al. 2020).

Many researchers have evaluated the time needed for COVID-19 virus to remain survive on inanimate objects, it was found that the survival time for COVID-19 virus on plastic and stainless steel is up to 72 hours, on copper need up to four hours, on cardboard is up to 24 hours. These values are not absolute and can be changed according to environmental conditions (WHO, FAO. 2020).

The response of food handlers in different Jordanian factories to knowledge, attitude and hygiene practice need re-evaluation during COVID-19 pandemic case and it is necessary to refresh their data in the principles of food hygiene to reduce and eliminate any hygienic risk lead to contaminate of food or food packaging and surfaces with viruses during processing, as well as reduce and eliminate food borne diseases (Sharif, L. et al. 2010). 
Food industry in Jordan is targeting millions of people from local population in addition to exported food products to different countries worldwide ( Osaili, T. et al. 2011). During COVID-19 pandemic the food processing faces strong competitions and challenges as consumers demand high quality and safe food products and the governmental agencies need to ensure safe consumption of food along the food processing chain.

Spreading COVID-19 virus among food workers in food factories will be common worldwide and prevent spreading virus have captured many organizations awareness all over the world. FAO and WHO (2020) identified the keys for controlling COVID-19 virus among food handlers which include awareness of food workers to COVID-19 symptoms, providing the food handlers in food factories with written documents for rules how to prevent spreading COVID-19 among them, changing the gloves by food workers frequently and washing their hands after changing and removing gloves, adhering with physical distancing at least $1.5 \mathrm{~m}$ and minimizing the contact among food workers, making control during transportation and delivery of food ingredients and food products by adhering with mentioned keys. Although the training of food handler will increase their knowledge about food safety but this may not reflect their positive attitude (Mitchell, R. et al. 2007).

Many studies were done to evaluate the hygienic practice and food safety knowledge for food handlers in restaurants before COVID-19 pandemic,in this study the overall hygienic practice, the food safety knowledge and the attitude of food handlers as well as the awareness of food workers to control COVID19 virus during COVID-19 pandemic in Jordanian food factories were conducted for the first time in Jordan.

\section{Materials And Methods \\ 2.1. Research design}

To assess the hygienic practice, food Safety knowledge and attitude among food workers during COVID19 pandemic in Jordanian food factories cross-sectional study where used.

\subsection{The respondents}

A total of 500 food workers from 25 food factory were participated in this study, the questionnaire were sent by e mails and other social media applications and filled electronically by the workers.

\subsection{Food safety knowledge questionnaire}

this study targets all food workers in food factories. Forty questions divided into 4 parts. each part consist from 15 questions about good hygiene practice, knowledge, attitude and COVID-19 awareness before and during COVID-19. The scores for answering knowledge and attitude questions were recorded 
on a five- point scale ranged from zero to four, with options of strongly agrees, agree, not sure, disagree or strongly disagree. But, the scores for answering the questions about hygienic practice and COVID-19 awareness were recorded on a five-point scale ranged from zero to four with options of always, most of the times, sometimes, rarely or never. The scale direction was (4 to 0$)$ and in some questions the scale was reversed to ( 0 to 4$)$ to check the validity of the responses. According to dichotomous classification, negative response (Answering wrong) was given for the score less than 3, a positive response (Answering right) was given for the scores 3 and 4 .

\section{4. statistical analysis}

Statistical Package for the Social Sciences, Version 15.0 (SPSS, Inc., Chicago, IL, USA) were used for statistical analyses in this study. The means, standard deviations, and frequencies were used as descriptive statistics. One way ANOVA test was used to compare between different parameters. results with a P-value $<0.05$ were considered to be statistically significant.

\section{Results}

\subsection{General features of the participants}

A total of 500 food handlers from 25 food factories were included in this study; 450 male and 50 female. The educational level for $60.3 \%$ was less than 10 years and had monthly income less than $400 \mathrm{~J}$. D. The participants used in this study were selected from different food factories from different geographical location in Jordan; from North (Irbid 8\%), East (ArRuayshid 8\%), Middle (Amman 40\% and AzZarqa 20\%), South ( Al Karak 16\%, Maan 8\%) Figure-1. The age of participants was ranged between 18-55, and the experience ranged from 5 to 15 years.

\subsection{Food handlers knowledge}

The knowledge of food handlers during COVID-19 pandemic was higher than their knowledge before COVID-19 pandemic with a mean percentage score of $83.4 \pm 8.3 \%, 73.3 \pm 10.8 \%$ respectively. The food handlers showed high knowledge in the sources of food contamination with food pathogens, food with high risk, risk factors for food poisoning, and storage conditions for food. In other hand, they demonstrated weak knowledge about reheating of cooked food, only $60 \%$ before COVID -19 and 67.5 after COVID-19 believed that previously prepared food should be reheated before eating. $65.5 \%$ before COVID-19 and 50\% during COVID-19 thought that the correct method for thawing frozen food is to keep them at room temperature. $40 \%$ before COVID-19 and $55.3 \%$ during COVID-19 from food handlers thought that healthy food workers might carry foodborne pathogens (Table 1).. previous study in South Africa to evaluate food handlers' knowledge on food hygiene $(n=159)$ in small and micro enterprises, the percentage of correct answers was in average 46.0\% (McSwane, D. et al. 2003) and in other study in Ankara, Turkey, the average of food safety knowledge score for food handlers $(n=764)$ was $43.4 \% \pm$ 
16.3\% (Bas, M. et al. 2006). In Portugal, It was found that food handlers represented good level of knowledge in personal hygiene and cross contamination, but fared worse in other areas in a study consist from 124 food handlers in 32 school canteens (Campos, A. et al. 2009). On the other hand, many studies showed that food handlers had unsatisfied level for knowledge about food hygiene issues (Belot, M. and James, J. 2009, Clayton, D. and Griffith, C. J. 2004).

Our study demonstrated that there is an improvement in the knowledge of food handler during COVID-19 pandemic comparing with their Knowledge before COVID-19. This result is related to increase in training courses and educational levels in food safety during COVID-19, since the governmental agencies provided most premises with written instructions and training in food safety issues. recently no studies are available about food safety knowledge during COVID-19. In general, our food handlers have a good knowledge in food poisoning comparing with other studies carried out in United Kingdom Turkey, Slovenia, Italy and Portugal which demonstrated that food handlers lack the knowledge regarding food poisoning (Afifi, H. S. \& Abushelaibi, A. 2012, Almanza, B. et al. 2007, Ansari-Lari, M. et al. 2010, Herztman, J. and Barrash, D. 2007, Hilton, J. 2002, Ko, W. H. 2010). 
Table 1

Response of food workers in different food factories in Jordan to knowledge questions on food poisoning before and during COVID:19.

\section{Question}

\section{Before During \\ COVID:19 COVID:19}

Positive

Answer

(\%)

1) Unwashed raw vegetables has high risk for food poisoning

2) Bad hygienic practice for food handlers is a real source for food contamination with food pathogens

3) Left cooked food for more than 3 hours at room temperature will cause food poisoning

4) Keep food at refrigerator help in preventing food poisoning

88.3

82.3

76.3

93.7

4) Keep food at refrigerator help in preventing food poisoning

5) Direct contact between workers hands and ready to eat food will cause direct food contamination with food borne pathogens

6) Left frozen food at room temperature for more than 12 hours is suitable method for thawing

7) In some cases food poisoning will cause death

84.5

88.8

65.5

50

8) Food workers doesn't show any food poisoning symptoms might carry food borne pathogens

9)Microbial numbers will increase rapidly at room temperature

10) Previously prepared food should be reheated before eating

11) Foodborne pathogens couldn't e be seen by naked eye

12) Meat and poultry should be placed on lower shelf in refrigerator than Vegetables

13) Pathogenic microbes will cause Food poisoning

14) Eating under cooked or raw food is highly risky for food poisoning

15) Flies and insects will transfer food borne pathogen
72.2

88.2

89.1

94.3

76.7

84.8
66.3

76.3

55.3

79.4

67.5

88.3

92.1

78.3

\subsection{Food Handlers' Attitude}

The answers of food handlers about attitude questions on food poisoning is presented in Table 2. In general, the food handlers attitude toward safe food handling during COVID-19 was higher than their attitude before COVID-19 with mean percentage score of $91.3 \% \pm 12.7$ and $88.36 \% \pm 10.7 \%$ respectively. 
Table 2

Response of food handlers in different food factories in Jordan to attitude questions on food poisoning before and during COVID-19.

\begin{tabular}{|c|c|c|}
\hline \multirow[t]{2}{*}{ Question } & $\begin{array}{l}\text { Before } \\
\text { COVID:19 }\end{array}$ & $\begin{array}{l}\text { During } \\
\text { COVID-19 }\end{array}$ \\
\hline & $\begin{array}{l}\text { Positive } \\
\text { Answer (\%) }\end{array}$ & $\begin{array}{l}\text { Positive } \\
\text { Answer (\%) }\end{array}$ \\
\hline 16) Keep food handling safe is one of my job responsibilities & 88.5 & 91.5 \\
\hline 17) Training and educations in food safety is very important & 89.5 & 96.5 \\
\hline $\begin{array}{l}\text { 18) Checking the temperature of the refrigerator is important to } \\
\text { prevent food poisoning }\end{array}$ & 90 & 95.4 \\
\hline 19) Separate between raw food materials and finish product & 83.5 & 88.9 \\
\hline 20) Food handlers is a good source for pathogenic microbes. & 93.0 & 98.2 \\
\hline $\begin{array}{l}\text { 21) Wiping vegetables and fruits without washing will make them } \\
\text { safe to be eaten }\end{array}$ & 98.0 & 65.4 \\
\hline $\begin{array}{l}\text { 22) Deep washing of vegetables and fruits is necessary to reduce } \\
\text { food poisoning. }\end{array}$ & 90 & 95.3 \\
\hline 23) Long hair and beard can transfer food borne pathogens & 66.3 & 75.1 \\
\hline 24) Foodborne pathogens can easily transfer by long fingernails & 90.5 & 96.4 \\
\hline $\begin{array}{l}\text { 25) Meat and raw vegetables should not be cut on the same cutting } \\
\text { plate }\end{array}$ & 78.7 & 88.4 \\
\hline $\begin{array}{l}\text { 26) Different cutting board should be used for meat and cheese ( } \\
\text { color-coding cutting plates) }\end{array}$ & 88.6 & 96.6 \\
\hline $\begin{array}{l}\text { 27) Medical examination should be done for food handlers every six } \\
\text { months }\end{array}$ & 90.4 & 98.5 \\
\hline $\begin{array}{l}\text { 28) Wiping the cutting plates will be enough to prevent spreading of } \\
\text { foodborne pathogens. }\end{array}$ & 86.4 & 67.5 \\
\hline $\begin{array}{l}\text { 29) washing hands with cold water without using soap is enough to } \\
\text { get rid food borne pathogens }\end{array}$ & 85.5 & 60.4 \\
\hline 30 food poisoning outbreak is most common in our life & 60 & 80 \\
\hline
\end{tabular}


Table 2

Response of food handlers to personal hygiene practice in different food factories in Jordan before and during COVID:19

\begin{tabular}{|c|c|c|}
\hline \multirow[t]{2}{*}{ Question } & $\begin{array}{l}\text { Before } \\
\text { COVID:19 }\end{array}$ & $\begin{array}{l}\text { During } \\
\text { COVID:19 }\end{array}$ \\
\hline & $\begin{array}{l}\text { Positive } \\
\text { Answer (\%) }\end{array}$ & $\begin{array}{l}\text { Positive } \\
\text { Answer (\%) }\end{array}$ \\
\hline $\begin{array}{l}\text { 31) Wearing gloves during handling ready to eat food or } \\
\text { preparing sandwiches. }\end{array}$ & 90.5 & 94.5 \\
\hline 32) Washing hands with water and soap before preparing food. & 71.5 & 98.5 \\
\hline $\begin{array}{l}\text { 33) Washing hands with water and soap after using the } \\
\text { bathroom? }\end{array}$ & 74 & 96 \\
\hline 34) Working during feeling with nausea, diarrhea and vomiting. & 74.5 & 85. \\
\hline $\begin{array}{l}\text { 35) Covering the lesions on hands during preparing food } \\
\text { product? }\end{array}$ & 79 & 93.6 \\
\hline 36) Sanitizing vegetables and fruits before slicing them. & 64.4 & 88.4 \\
\hline $\begin{array}{l}\text { 37) Keeping cooked food product at room temperature for more } \\
\text { than } 4 \text { hours. }\end{array}$ & 74.3 & 85.7 \\
\hline $\begin{array}{l}\text { 38) Cleaning food contact surfaces before and after preparing } \\
\text { food. }\end{array}$ & 70.5 & 89.5 \\
\hline 39) Working if you have cold. & 666 & 98.6 \\
\hline $\begin{array}{l}\text { 40) Washing fresh vegetables and fruits in tap water before } \\
\text { eating. }\end{array}$ & 79.5 & 90.5 \\
\hline $\begin{array}{l}\text { 41) Washing your hands with water and soap before eating } \\
\text { your meal. }\end{array}$ & 65.5 & 94.5 \\
\hline 42) Separating raw food materials from finish products. & 77.7 & 87.6 \\
\hline 43) Checking the temperature of the refrigerator by intervals. & 87.5 & 90.9 \\
\hline 44) Using mouth mask during processing time. & 41.8 & 99.7 \\
\hline $\begin{array}{l}\text { 45) Wearing arm protection (sleeve) during preparing food } \\
\text { products. }\end{array}$ & 76.8 & 98.6 \\
\hline
\end{tabular}

\subsection{Practice the food workers for personal hygiene}

The response of food workers to good personal hygiene practice before and during COVID-19 is presented in Table 3. In general, the result showed good hygiene level for food handlers before and during COVID-19 with a mean percentage score of $74.54 \% \pm 11.6 \%$ and $93.61 \% \pm 13.6$. They have weak concept in hygienic practice before COVID-19. In general, most of them show attention about the 
hygienic rules of preparing food as covering the lesions, washing fresh vegetables and fruits in tap water before eating, wearing gloves during handling food products during preparing food products, separating raw food materials from finished food products. the results showed good improvement in their responses during COVID-19 such as cleaning and sanitizing food contact surfaces before and after preparing food, keeping food at room temperature more than 4 hours, washing their hands with water and soap after using the bathroom, and using mask during processing time. This study showed that weak correlation between the knowledge and food hygiene practice. that means good knowledge doesn't necessarily result in good hygiene practice (Azjen, I. and Fishbein, M. 1980). Therefore, the training and educational courses for food workers should focus on critical non conformities and risk perception that may lead to unsafe practices (Centers for Disease Control and Prevention, 2002). 
Table 4

Response of food handlers in different Jordanian factories for their awareness about COVID-19 requirements.

\section{Question}

during COVID:19

$\begin{array}{ll}\text { (\%) of } & \text { (\%) of } \\ \text { positive } & \text { Negative } \\ \text { response } & \text { response }\end{array}$

46)The company measure the employee's temperature and assess their COVID:19 symptoms(fever, cough, or shortness of breath ) prior to them

90.3

9.7 starting work.

47) You should maintain 6 feet and keep social distancing as work duties $\quad 80.5 \quad 19.5$ permit in the workplace.

48) You should clean and disinfect all working areas such as working

76.4

23.6 surfaces, common areas, shared electronic equipment routinely.

94) You should inform the supervisor about your family member at home suffered from COVID-19 symptoms .

50) Corona viruses need host cell to multiply, so it cannot multiply in food.

84

16

51) Corona viruses can spread person-to-person by coughing or sneezing. $\quad 88.5$

11.5

52) The virus will stay viable on plastic and stainless steel up to 72 hours, 35 65 on copper, up to four hours and on cardboard up to 24 hours.

53) Face Masks and gloves can effectively reduce spreading corona 82.1 17.9 virus.

54) wearing gloves is not a substitute for hand washing.

46

54

55) food workers should be provided with rules and instructions related to

70

30

prevent spreading corona virus.

56) Food workers should not use cash money, instead they could use

54.7

45.3 contactless payment.

57) Staff delivering to food premises should not leave their vehicles during $\quad 51.5$

48.5 delivery.

58) Food delivers should be aware about physical distancing when they

84.4

15.6 pick up food and passing deliveries to other customers

59)The company should use special marks on the floor to facilitate physical distancing between workers, specialy in crowded areas.

70.6

29.4

60) The company should used regular reminders for customers about following physical distancing cleaning their hands regularly

40.5

59.5

The awareness of food handlers in Jordanian factories for COVID-19 requirements is presented in Table 4. In general, the results showed good awareness for the food handlers about COVID-19 requirements 
with a mean percentage score of $70.4 \% \pm 14.9 \%$. They have weak concept in scientific facts about corona virus, $44.5 \%$ demonstrated that corona virus can multiply in food, $35 \%$ conducted that virus will stay viable for 72 hours on plastic and stainless steel, 4 hours on copper, and 24 hours on cardboard. $54 \%$ of food handlers believed that wearing disposable gloves will be a substitute for hand washing in the food work environment. $51.5 \%$ of staff delivering food and other drivers to food premises showed that they should not leave their vehicles during delivery. Only $40 \%$ of food companies used regular reminder for customers to follow physical distancing advice and clean their hands regularly and only $54.7 \%$ food premises encouraging the use of contactless payments. In general, most of them show good attention about COVID:19 symptoms: fever, cough, shortness of breath, keeping at least 6 feet as social distancing in the workplace and when picking up deliveries from customers, methods for spreading the virus from person-to-person by coughing and sneezing.

\section{Conclusion}

The recent research shows valuable data about the level of awareness about COVID-19 requirements, personal hygiene practice, knowledge and attitude for food workers in food factories. The overall scores for this study were $79.13 \%$. Enforcement the governmental regulations, increasing the number of, training courses and incentive the positive attitude of food handlers would improve the status of food hygiene during COVID-19.

\section{Declarations}

Ethics approval:

The author declares no animals or human or even tissues used in this study.

\section{Consent for publication:}

The author declares that there is consent for publication

\section{Availability of data and material:}

Please contact author for data requests.

\section{Competing interests:}

The author declares no potential conflict of interests.

\section{Funding:}


This research was supported by a Grant from Deanship of Scientific Research at Al-Balqa Applied University. Salt, Jordan.

\section{Authors' contributions:}

Main Author write, edit and do research

\section{Acknowledgment:}

the researcher appreciate the efforts of Deanship of Scientific Research at Al-Balqa Applied University. Salt, Jordan

\section{References}

1. Afifi, H. S. \& Abushelaibi, A. A. (2012). Assessment of personal hygiene knowledge, and practices in Al Ain, United Arab Emirates. Food Control, 25(1), 249253.

2. Almanza, B. A, Namkung, Y., Ismail, J. A. \& Nelson, D.C. (2007). Clients safe food-handling knowledge and risk behavior in a home-delivered meal program. Journal Of The American Dietetic Association, 107(5), 81621.

3. Ansari-Lari, M., Soodbakhsh, S. \& Lakzadeh, L. (2010). Knowledge, attitudes and practices of workers on food hygienic practices in meat processing plants in fars, Iran. Food Control, 21, 260-263.

4. Azjen, I. \& Fishbein, M. (1980). Understanding attitudes and predicting social behavior. Prentice Hall Inc.

5. Bas, M., Ersun, A. S. \& Kivanc, G. (2006). The evaluation food businesses in Turkey. Food Control, 17, 317-322.

6. Belot, M. \& James, J. (2009). Healthy school meals and educational outcomes. Economic \& social research council. ISER working paper series. www.iser.essex.ac.uk. New Food, 5(3),80-2.

7. Centers for Disease Control and Prevention. (2000). Surveillance for foodborne disease outbreak United States, 1993-1997.

8. Clayton, D. A. \& Griffith, C. J. (2004). Observation of food safety practices in catering using notational analysis. British Food Journal, 106(3), 211-227.

9. Codex Alimentarius Commission, Joint FAO/WHO Standards Programme. (2003). Food hygiene: Basic texts. 2nd Edition.

10. Campos, A., Karina, C. Cardonha, M. and Soares, P.(2009). Assessment of personal hygiene and practices of food handlers in municipal public schools of Natal, Brazil. Food Control, 20,807-810.

11. Food and Agriculture Organization/World Health Organization. (2004). Regional conference on food safety for the Asia and the Pacific, Seremban. Retrieved from www.fao.org/DOCREP/MEETING/006/AD698E.HTM. 
12. Herztman, J. \& Barrash, D. (2007). An assessment of food safety knowledge and practices of catering employees. British Food Journal, 109(7), 562-576.

13. Hilton, J. (2002). Reducing foodborne disease: Meeting the targets. Nutrition \& Food Science, 32(2), 46-50.

14. Ko, W. H. (2010). Evaluating food safety perceptions and practices for agricultural food handler. Food Control, 21, 450-455.

15. McSwane, D., Rue, N., \& Linton, R. (2003). Essentials of food safety and sanitation. Third Edition. Pearson Education. New Jersey.

16. Mitchell, R. E., Fraser, A.M. \& Bearon, L. B. (2007). Preventing food-borne illness in food service establishments: Broadening the framework for intervention and research on safe food handling behaviors. International of Environmental Health Research, 17(1), 9-24.

17. Osaili, T. M., Obeidat, B. A., Abu Jamous, D. O. \& Bawadi, H. A. (2011). Food safety knowledge and practices among college female students in North Of Jordan. Food Control, 22(2), 269276.

18. Sharif, L and Al-Malki, T. (2010). Knowledge, Attitude and Practice of Taif University Students on Food Poisoning. Food Control, 21, 55-60.

19. Tong, Z., Tang, A. Li, K, Li, P., Wang, L. (2020). Potential presymptomatic transmission of SARS-CoV2, Zhejiang Province, China, Emerg Infect Dis.

20. Wei, W. E., Li Z, Chiew, C. J., Yong, S. E. (2020). Presymptomatic Transmission of SARS-CoV-2Singapore. MMWR,1-2.

21. WHO, FAO. ( 2020). COVID-19 and Food Safety: Guidance for Food Businesses: interim guidance,

\section{Figures}




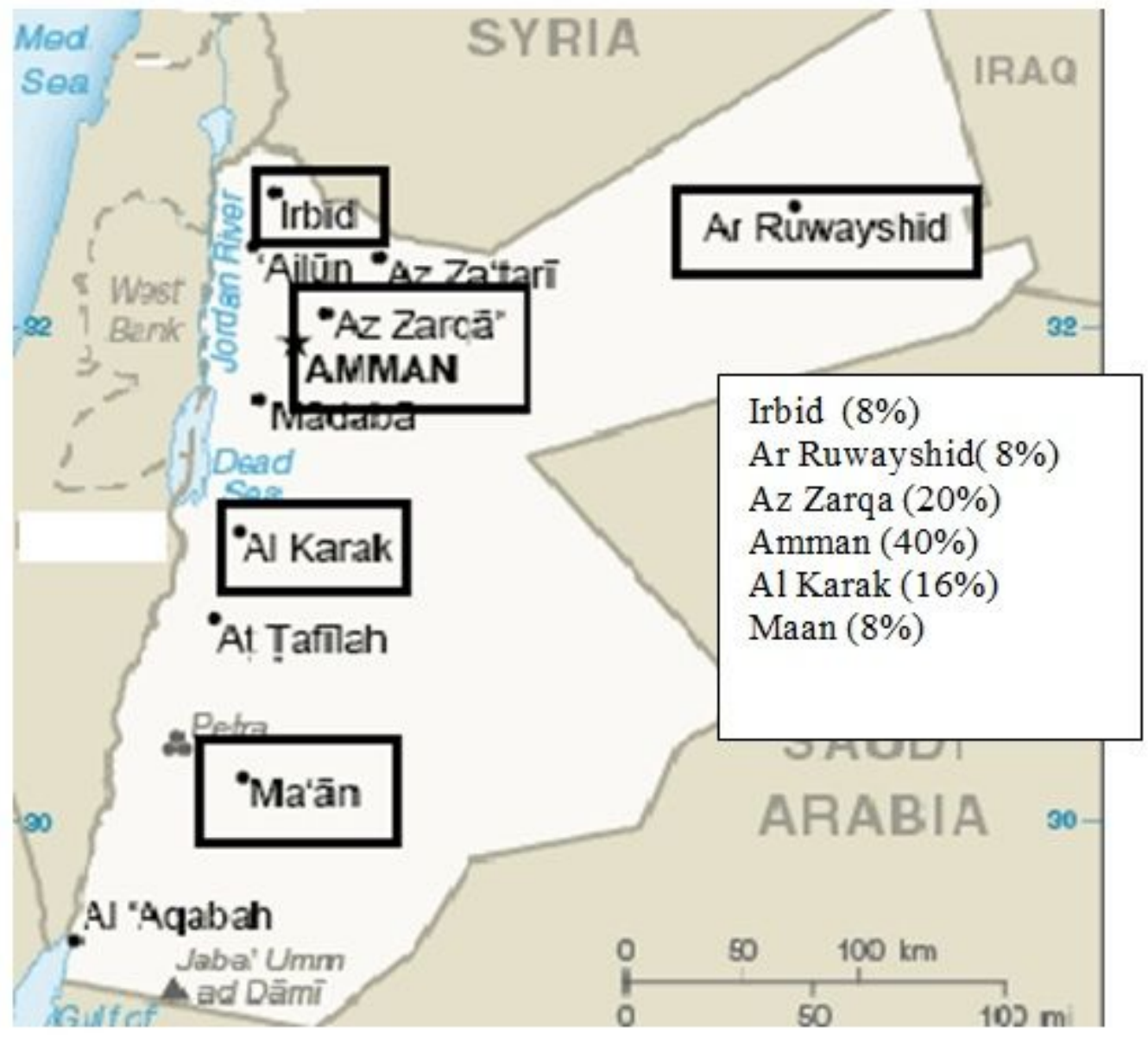

Figure 1

The geographical location for food factories used in this study 